\title{
DETERMINANTS OF AGRICULTURAL LOAN DECISION MAKING PROCESS FOR RICE (ORYZA SATIVA) FARMERS IN ABUJA, NIGERIA. APPLICATIONS OF HECKMAN TWO-STAGE MODEL AND FACTOR ANALYSIS
}

\author{
Olugbenga Omotayo Alabi ${ }^{1 凶}$, Ayoola Olugbenga Oladele ${ }^{2}$, \\ Mohammed Bello Usman² \\ ${ }^{1}$ University of Abuja, Nigeria \\ ${ }^{2}$ Forestry Research Institute of Nigeria, Nigeria
}

\begin{abstract}
This study focuses on determinants of the agricultural loan decision-making process of rice (Oryza sati$v a$ ) farmers in Abuja, Nigeria, using the Heckman two-stage model and factor analysis. This study was designed specifically to achieve the following objectives: determine the socio-economic profiles or characteristics of rice farmers, analyze the costs and returns of rice production, evaluate factors influencing rice farmers' decision to obtain an agricultural loan, evaluate socio-economic factors influencing the amount of the agricultural loan, and determine the constraints or problems facing rice farmers. A multi-stage sampling design was employed. A total sample of one hundred (100) rice farmers was included, and primary data were utilized. Data were obtained through the use of a well-structured and well-designed questionnaire. Statistical and econometric tools used in analyzing data included descriptive statistics, gross margin analysis, financial analysis, the Heckman two-stage model, and principal component analysis. The results show that $63 \%$ of rice farmers were between the age of $31-50$ years. The mean age was 41.90 years. About $65 \%$ of rice farmers were male, and $54 \%$ of them were married. Also, 93\% of rice farmers had formal education and were literate. The household sizes were large, with an average of six persons per household. An average of 71,550 nairas was the loan amount granted to rice farmers by financial institutions. The average farm size amounted to 1.49 hectares. Factors
\end{abstract}

influencing the decision of rice farmers to obtain agricultural loan included age $(P<0.01)$, marital status $(P<0.05)$, household size $(P<0.10)$, educational level $(P<0.05)$, farm size $(P<0.05)$, farm and non-farm income $(P<0.10)$, farm experience $(P<0.05)$, collateral property $(P<0.05)$, extension services $(P<0.10)$, and awareness of loan or credit facilities $(P<0.05)$. Rice production was profitable with a net farm income of 744,300 nairas. The gross margin ratio of 0.95 means that 95 kobos covered profits, taxes, expenses, interest, and depreciation for every naira invested in rice production activities. Socio-economic factors statistically and significantly influencing the amount of agricultural loan obtained by rice farmers included $(P<0.05)$ sex $(P<0.01)$, household size $(P<0.05)$ and educational level $(P<0.01)$. The constraints facing rice farmers in obtaining the agricultural loan and production activities included lack of collateral property, lack of fertilizer input, poor-quality feeder roads, lack of credit facilities, inadequate labor input, and complicated and costly administrative procedures to obtain a loan. It is recommended that agricultural loans be made available to rice farmers in sufficient amounts and at low-interest rates. Also, farm inputs, fertilizer inputs, improved seeds, and chemicals should be made available to rice farmers.

Keywords: agricultural loan decision, Heckman two-stage model, rice farmers, Nigeria

\footnotetext{
$\bowtie$ Olugbenga Omotayo Alabi, Department of Agricultural-Economics, University of Abuja, PMB 117 Gwagwalada-Abuja, Nigeria, e-mail: omotayoalabi@yahoo.com, https://orcid.org/0000-0002-8390-9775
} 


\section{INTRODUCTION}

The agricultural sector is the mainstay for sustainable economic growth, providing employment, wealth, raw materials for industrial sectors, and foreign exchange earnings for Nigeria (Nkamigbo et al., 2019). Rice (Oryza sativa) is the essential staple in the world and food security product in Nigeria (Agbogo et al., 2013). Rice is cultivated in almost all agro-ecological zones of Nigeria (FAOSTAT, 2005). The national output of rice production was 5.9 million metric tons in 2013 . The increase in rice production was attributed to the expansion in the area in hectares cultivated. The acreage of land cultivated for rice in 2013 was 2.6 million hectares (FMARD, 2014). The consumption of rice has risen over the past period. An average Nigerian consumes $24.8 \mathrm{~kg}$ of rice per year (IRRI, 2001). The rice consumption has increased more than its production in Nigeria, with the country depending on imports. The domestic production of rice lags behind the demand in Nigeria. Inadequate capital is one of the problems facing farmers, agricultural productivity, and economic growth in Nigeria (Alabi et al., 2016). However, the agricultural sector, which constitutes $42 \%$ of GDP, is the least favored in terms of loans and advances by commercial banks (Eboh et al., 2011).

An agricultural loan from formal sources can be defined as money given or extended to farmers for agricultural activities, which enhances productivity, increases production, and improves the living standard and wellbeing of the farmer (Alabi et al., 2016). CBN (2008) observed that about $2.5 \%$ of commercial bank total loans and advances were extended to the agricultural sector. Commercial banks were reluctant to grant loans for farming activities in Nigeria. Commercial banks usually refer to smallholder farmers as unbankable and high risk; they adopt risk-averse attitudes towards those farmers (Nwaru, 2011; Essien et al., 2013). Institutionalized agricultural loans are characterized by rigorous processes and stringent conditions of the acquisition. Collaterals are demanded before loans are extended to farmers. One way to increase farm output and improve farmers' efficiency and productivity is to make the agricultural loans more readily available to farmers. Agricultural loans, sometimes called agricultural credit from formal sources, provide the resources needed by farmers that the smallholder farmers cannot source using their savings. The loanable fund, agricultural credit, or provision of these inputs determine the access to all other inputs farmers depend upon in their farming activities. Agricultural loan or agricultural credit is essential for the agricultural sector development. It can increase agricultural productivity, reduce poverty among the populace, and increase Nigeria's economic growth. Agricultural loans can be seen as the critical method of solving the problems of rice farmers. The vicious cycle of poverty is broken, and low income and low productivity are addressed (Bamiro et al., 2012). The amount of credit available to rice farmers is often inadequate. Therefore, rice farmers cannot realize their full potentials. Agricultural loans extended to rice farmers can improve the allocation of resources, increase profit margin, and increase the managerial efficiency of rice farmers (Bashir et al., 2010). Availability of agricultural credit and timely disbursement of the loans to farmers are essential for farmers to acquire farm inputs and carry out farm activities (Saboor et al., 2009). The credit markets for rural farmers are made of formal and informal sources. Despite the increasing importance of formal credit to farmers, rice farmers had limited access to it. The adoption of modern and efficient technologies by farmers was limited by capital or credit constraints. Rice farmers need capital or credit to buy an improved high-yielding variety of seeds, fertilizers, chemicals, pay for labor. Also, farmers preparing for the next farming season need capital to cater to their latest crop cash shortages and non-payment. When capital or credit is available, farmers' consumption pattern is satisfied, inputs are correctly used, and farmers' livelihoods are improved (Saqib et al., 2018). When rice farmers have access to an agricultural loan or credit, they can expand their farms, adopt innovative research findings, novel technologies and diversify their farm operations. The provisions of agricultural credit enable rice farmers to mobilize resources for more productive purposes, increasing their income. The terms of lending by formal financial institutions with collaterals inclusive and the repayment terms hinder farmers from obtaining agricultural credit.

\section{OBJECTIVES OF THE STUDY}

The objectives of this study are broadly focused on determinants of the agricultural loan decision-making process of rice (Oryza sativa) farmers in Abuja, Nigeria, using the Heckman two-stage model and factor analysis. 
Specifically, the study was designed to achieve the following goals:

(i) determine the socio-economic profiles or characteristics of rice farmers

(ii) analyze the costs and returns of rice production

(iii) evaluate factors influencing rice farmers' decision to apply for an agricultural loan

(iv) evaluate socio-economic factors influencing the amount of agricultural loan obtained, and

(v) determine the constraints or problems facing rice farmers.

\section{METHODOLOGY}

\section{The study area}

The study was conducted in Gwagwalada, Abuja, Nigeria. Gwagwalada is an area council located at latitudes $8055^{\prime} 59^{\prime \prime}$ north of the equator and longitudes 70 ' 59" east of the meridian. The study area was characterized by high humidity, which has a heat trap effect. There are notably two main seasons: wet and dry. Annual rainfall ranges from $1,100 \mathrm{~mm}$ to $1,700 \mathrm{~mm}$. The climatic conditions of the study area permit agricultural activities such as the cultivation of crops, grazing of animals, and fishery production. Gwagwalada Area Council has a total landmass of about 1,043 square kilometers and 157,770 population (NPC, 2006). The average annual rainfall ranges from 800 to $1,500 \mathrm{~mm}$, and temperature ranges between $21-35^{\circ} \mathrm{C}$. Crops grown in the area include rice, yam, garden egg, maize, millet, sorghum, cassava, etc.

\section{Sampling techniques and sample size}

The purposive sampling technique was adopted and employed in choosing Abuja, Nigeria. It was selected due to the large number of smallholder rice farmers in the area. Multi-stage sampling was adopted and employed in selecting the rice farmers. The first stage involved selecting Gwagwalada out of six (6) area councils. The second stage consisted of selecting five (5) out of ten (10) wards. The third stage involved selecting two (2) villages per ward. The fourth and final stage involved selecting five (5) rice farmers as the target respondents; a simple random sampling technique employing the ballot-box raffle draw method was used for all four stages. The total sample consisted of 100 rice farmers from the above area.

\section{Method of data collection}

This study employed primary data. Primary data involve the use of a well-designed and well-structured questionnaire. The questionnaire was designed to capture all variables necessary to achieve the broad and specific objectives stated. The questionnaire captured variables concerning rice farmers' socio-economic characteristics, including age, household size, rice production experience, marital status, and educational status. The questionnaire was also designed to capture the cost involved and revenue obtained from rice production, access to agricultural loan, amount of agricultural loan accessed, rice production output, and constraints or problems facing rice farmers. The questionnaire was subjected to reliability and validity tests. The observations arising from said tests were considered in the questionnaire design. The questionnaire was administered to rice farmers with the help of well-trained enumerators.

\section{Method of data analysis}

The following statistical and econometric tools were applied to achieve the stated broad and specific objectives:

(i) descriptive statistics

(ii) gross margin analysis

(iii) financial analysis

(iv) Heckman two-stage model

(v) principal component analysis, and

(vi) t-test analysis.

\section{Descriptive statistics}

This method involved or encompassed the use of mean, frequency distributions, percentages. Descriptive statistics were applied to create summary statistics of the data obtained from the field research. It enabled achieving specific objectives one (i) and five (v), leading to identifying rice farmers' socio-economic characteristics and constraints or problems facing them.

\section{Gross margin analysis}

Gross margin analysis is defined as the difference between the observed gross farm income (GFI) and total variable cost (TVC) (Olukosi and Erhabor, 2005). It was used to determine the potential profitability of marginal maize farmers. This tool was used to achieve specific objective two (ii).

The gross margin model (GM) is expressed as follows: 


$$
G N=T R-T V C
$$

where:

$G M$ - gross margin (

$T R$ - total output value or total revenue of rice farmers ( $\mathrm{N})$

$T V C$ - total variable cost (N)

and

$$
T R=P \cdot Q(\mathrm{~N})
$$

where:

$P$ - price of rice produced in naira per kilogram

$Q$ - output of rice produced in kilogram

Net farm income (NFI) is stated thus:

$$
N F I=\sum_{i=1}^{n} P_{1} Y_{i}-\sum_{j=1}^{m} P_{j} X_{j}-\sum_{k=1}^{k} G K
$$

$N F I$ - net farm income (naira per annum)

$P_{i} \quad$ - product unit price (naira/unit)

$P_{j} \quad$ - price per unit variable input (naira/unit)

$G K$ - total fixed input cost (where $k=1,2,3, \ldots k$ fixed input)

$\sum-$ summation or addition signs

It was used to achieve part of specific objective two (ii).

\section{Financial analysis}

The gross margin ratio (GMR) following Ben-Chendo et al. (2015) was used to determine rice production profitability. It was used to achieve part of specific objective two (ii):

$$
\text { Gross Margin Ratio }=\frac{\text { Gross Margin }}{\text { Total Revenue }}
$$

In order to evaluate the strength and financial positions of rice enterprises, the operating ratio and rate of return per naira invested were considered. An operating ratio (OR), according to Olukosi and Erhabor (2005), is stated thus:

$$
O R=\frac{T V C}{G I}
$$

where:

$O R$ - operating ratio (units)

$T V C$ - total variable cost (naira)

GI - gross income (naira)
An operating ratio (OR) that is less than one (1) implies that the total revenue obtained from rice production was enough to pay for the cost of variable inputs used in the enterprise (Olukosi and Erhabor, 2005). The rate of return per naira invested (RORI) in rice production is stated thus:

$$
R O R I=\frac{N I}{T C}
$$

where:

$R O R I$ - rate of return per naira invested (units)

NI - net income from marginal maize production (naira),

TC - total cost (naira).

The financial analysis was used to achieve part of specific objective two (ii).

\section{Heckman two-stage model}

(a) Probit model analysis

The probit model is stated thus:

$$
\begin{gathered}
Z_{i}=f\left(X_{1}, X_{2}, X_{3}, X_{4}, X_{5}, X_{6}, X_{7}, X_{8}, X_{9}, X_{10}, X_{11}, U_{i}\right) \\
Y_{i}=b_{0}+\sum_{i=1}^{11} b_{i} X_{i}+U_{i}
\end{gathered}
$$

The explicit function is stated thus:

$$
\begin{gathered}
Y_{i}=b_{0}+b_{1} X_{1} \ldots+b_{10} X_{10}+U_{i} \\
Z_{i}=\beta_{0}+\beta_{1} X_{1}+\beta_{2} X_{2}+\beta_{3} X_{3}+\beta_{4} X_{4}+\beta_{5} X_{5}+ \\
\beta_{6} X_{6}+\beta_{7} X_{7}+\beta_{8} X_{8}+\beta_{9} X_{9}+\beta_{10} X_{10}+\beta_{11} X_{11}+U_{i}
\end{gathered}
$$

where:

$Z_{i}$ - dichotomous decision of rice farmers to obtain an agricultural loan ( 1 - access; 0 - otherwise)

$X_{1}$ - age of rural rice farmers (years)

$X_{2}$ - sex dummy ( 1 - male; 0 - female $)$

$X_{3}$ - marital status ( 1 - married; 0 - otherwise)

$X_{4}$ - household size (units)

$X_{5}$ - educational level ( 0 - non-formal; 1 - primary; 2 - secondary; 3 - tertiary)

$X_{6}$ - farm size (hectares)

$X_{7}$ - farm and non-farm income (naira)

$X_{8}$ - farm experience (years)

$X_{9}$ - collateral property ( 1 - available; 0 - otherwise)

$X_{10}$ - extension services dummy (number of extension contact in a month)

$X_{11}-$ awareness of loan or credit facilities ( 1 - aware; 0 - otherwise) 
$\beta_{1}-\beta_{11}-$ regression coefficients

$\beta_{0}-$ constant term

$U_{i}$ - error term

It was used to achieve specific objective three (iii).

\section{(b) Ordinary least squares regression model (OLS)}

The ordinary least square regression model is stated thus:

$$
Y_{i}=b_{0}+\sum_{i=1}^{12} b_{i} X_{i}+\varepsilon_{i}
$$

The explicit function is stated:

$$
\begin{gathered}
Y_{i}=\beta_{0}+\beta_{1} X_{1}+\beta_{2} X_{2}+\beta_{3} X_{3}+\beta_{4} X_{4}+\beta_{5} X_{5}+ \\
\beta_{6} X_{6}+\beta_{7} X_{7}+\beta_{8} X_{8}+\beta_{9} X_{9}+\beta_{10} X_{10}+\beta_{11} X_{11}+ \\
\beta_{12} X_{12}+\varepsilon_{i}
\end{gathered}
$$

where:

$$
\begin{aligned}
& Y_{i}-\text { amount of loan accessed (naira) } \\
& X_{1}-\text { age of rice farmers (years) } \\
& X_{2}-\text { sex dummy }(1-\text { male; } 0 \text { - female) } \\
& X_{3}-\text { marital status }(1-\text { married; } 0 \text { - otherwise) } \\
& X_{4} \text { - household size (units) } \\
& X_{5} \text { - educational level }(0-\text { non-formal; } 1 \text { - primary; } \\
& \quad 2 \text { - secondary; } 3 \text { - tertiary) } \\
& X_{6} \text { - farm size (hectares) } \\
& X_{7}-\text { farm and non-farm income (naira) } \\
& X_{8}-\text { farm experience (years) } \\
& X_{9}-\text { collateral property }(1-\text { available; } 0-\text { otherwise) } \\
& X_{10}-\text { extension services dummy (number of exten- } \\
& \quad \text { sion contact in a month) } \\
& X_{11}-\text { awareness of loan/credit facilities }(1-\text { access; } \\
& \quad 0 \text { - otherwise) } \\
& X_{12}-\text { inverse mill ratio (units) } \\
& \beta_{1}-\beta_{12}-\text { regression coefficients } \\
& \beta_{0}-\text { constant term } \\
& \varepsilon_{i}-\text { error term }
\end{aligned}
$$

It was used to achieve specific objective four (iv).

\section{Principal component analysis (PCA)}

As stated in specific objective five (v), rice farmers' perceived constraints or problems were analyzed using principal component analysis (PCA). The principal component analysis (PCA) model is stated thus:

$$
\begin{gathered}
x=x_{1}, x_{2}, x_{3}, \ldots, x_{p} \\
\alpha_{k}=\alpha_{1} k_{1}, \alpha_{2} k_{2}, \alpha_{3} k_{3}, \ldots, \alpha_{p} k_{p}
\end{gathered}
$$

$$
\alpha_{K}^{T} x=\sum_{j=1}^{p} \alpha_{K j X j}
$$

$$
\operatorname{Var}=\left[\alpha_{K}^{T} X\right] \text { is Maximum }
$$

Subject to

$$
\begin{gathered}
\alpha_{K}^{T} \alpha_{K}=1 \\
\text { and } \operatorname{Cov}=\left[\alpha_{1}^{T} \alpha-\alpha_{2}^{T} \alpha\right]=0
\end{gathered}
$$

The variance of each of the principal components:

$$
\begin{gathered}
\operatorname{Var}\left[\alpha_{K} X\right]=\lambda_{k} \\
S=\frac{1}{n-1}(X-\bar{X})(X-\bar{X})^{T} \\
S_{i}=\frac{1}{n-1} \sum_{i=1}^{n}\left(X_{i}-\bar{X}_{i}\right)\left(X_{I}-\bar{X}_{i}\right)
\end{gathered}
$$

where:

$X$ - vector of ' $\mathrm{P}$ ' random variables

$\alpha_{k}$ - vector of 'P' constraints

$\lambda_{k}-$ eigenvalue

$T$ - transpose

$S$ - sample covariance matrix.

\section{RESULTS AND DISCUSSION}

\section{Socio-economic profiles or characteristics of rice farmers}

Table 1 shows that $63 \%$ of rice farmers fell within the age range of $31-50$ years; the average age 46.90 years. It means that rice farmers were energetic and resourceful in their youthful age. Activities involved in rice production require a lot of energy; many rice farmers sampled were young and could undertake rice production. About $65 \%$ of rice farmers were male, and $54 \%$ of them were married. Education of farmers is vital for adopting novel technologies, including improved seeds, fertilizers, chemicals, and research findings (Alabi, 2008; Alabi et al., 2016). Furthermore, $93 \%$ of rice farmers had formal education and were literate. Moreover, $71 \%$ of farmers had between 1-10 years of experience in rice farming. The average farming experience amounted to 8 years. The household size was predominantly large; $86 \%$ of rice farmers had fewer than 10 members in their household. An average of 6 persons was found based on the 
Table 1. Socio-economic profiles or characteristics of rice farmers

\begin{tabular}{|c|c|c|c|}
\hline $\begin{array}{c}\text { Socio-economic profiles or } \\
\text { characteristics }\end{array}$ & Freq. & Percentage & Mean \\
\hline \multicolumn{4}{|l|}{ Age (years) } \\
\hline $31-40$ & 23 & 23.00 & 46.90 \\
\hline $41-50$ & 40 & 40.00 & \\
\hline $51-60$ & 37 & 37.00 & \\
\hline \multicolumn{4}{|l|}{ Sex } \\
\hline Male & 65 & 65.00 & \\
\hline Female & 35 & 35.00 & \\
\hline \multicolumn{4}{|l|}{ Marital status } \\
\hline Single & 32 & 32.00 & \\
\hline Married & 54 & 54.00 & \\
\hline Widowed & 08 & 08.00 & \\
\hline Divorced & 06 & 06.00 & \\
\hline \multicolumn{4}{|l|}{ Educational status (years) } \\
\hline Primary & 23 & 23.00 & \\
\hline Secondary & 43 & 43.00 & \\
\hline Tertiary & 27 & 27.00 & \\
\hline Non-formal & 07 & 07.00 & \\
\hline \multicolumn{4}{|c|}{ Experience in rice farming (years) } \\
\hline $1-5$ & 37 & 37.00 & 8.00 \\
\hline $6-10$ & 34 & 34.00 & \\
\hline $11-15$ & 21 & 21.00 & \\
\hline $16-20$ & 08 & 08.00 & \\
\hline \multicolumn{4}{|l|}{ Household size (units) } \\
\hline $1-5$ & 52 & 52.00 & 6.10 \\
\hline $6-10$ & 34 & 34.00 & \\
\hline $11-15$ & 14 & 14.00 & \\
\hline \multicolumn{4}{|l|}{ Access to loans (units) } \\
\hline Yes & 89 & 89.00 & \\
\hline No & 11 & 11.00 & \\
\hline \multicolumn{4}{|l|}{ Amount of loan (naira) } \\
\hline $0-10,000$ & 12 & 12.00 & 71,550 \\
\hline $10,000-50,000$ & 29 & 29.00 & \\
\hline $50,001-100,000$ & 27 & 27.00 & \\
\hline $100,001-150,000$ & 28 & 28.00 & \\
\hline$>150,000$ & 04 & 04.00 & \\
\hline \multicolumn{4}{|l|}{ Farm size (hectares) } \\
\hline$<1$ & 33 & 33.00 & 1.49 \\
\hline $1-2$ & 43 & 43.00 & \\
\hline $2-3$ & 16 & 16.00 & \\
\hline $3-4$ & 08 & 08.00 & \\
\hline Total & 100 & 100.00 & \\
\hline
\end{tabular}

Source: field survey, 2019. Computed using STATA Version 14. survey per rice farmer household. The mean amount of loan obtained by rice farmers was 71,550 nairas from various financial institutions. About $29 \%$ of rice farmers received loans ranging from 10,000-50,000 nairas. The average farm size for rice production activities was 1.49 hectares. And rice producers could be classified as small-scale or peasant farmers; $43 \%$ of farmers had between 1-2 hectares of farmland. It implies that as rice farmers gain farming experiences and age, both the rate of adopting agricultural technologies and productivity become lower. These findings are in line with Alabi et al. (2004; 2020), Lawal and Alabi (2011), who observed that the rate of adopting agricultural technologies becomes lower with the advancing age of farmers. The age of farmers is linked with experience in farming activities acquired by farmers.

\section{Costs and returns analysis of rice production}

The costs involved and revenue obtained in the activities of rice production were presented in Table 2. The revenue was estimated based on the current market prices at the time of this survey. The total variable cost was estimated at 38,500 nairas, which accounted for $69 \%$ of rice production costs. The total variable costs comprise of cost of land preparation (4\%), nursery and transplanting (2\%), fertilizer input (38\%), labor input (13\%), pesticides $(5 \%)$, and harvesting (7\%). The fixed cost accounted for $31 \%$ of the total cost of producing rice by farmers. The fixed cost consists of farm assets depreciation $(7 \%)$, cost incurred on land $(9 \%)$, expenses on administrative procedures (8\%), taxes (4\%), and interest (3\%). The gross margin and net farm income from rice production were 761,500 nairas and 744,300 nairas, respectively. It means that rice production was a profitable enterprise. This is in line with the findings of Alabi et al. (2020), Lawal and Alabi (2011), who reported in their research those positive values of gross margin and net farm income indicative of a profitable enterprise. The operating ratio, gross margin ratio, and rate of return on investment were $0.051,0.951$, and 13.36 , respectively. The gross margin ratio of 0.95 implies that 95 kobos cover profits, taxes, interest, expenses, and depreciation for every naira spent on rice production activities. These findings are in line with Alabi (2008), and Alabi et al. $(2004 ; 2016)$, who reported in their findings similar values of gross margin ratios and net returns on rice farming activities. 
Table 2. Costs and returns of rice production

\begin{tabular}{|c|c|c|}
\hline Variable & Value ( & Percentage \\
\hline \multicolumn{3}{|l|}{ (a) Variable Cost } \\
\hline Cost of land preparation & 2,000 & 04.00 \\
\hline Nursery/Transplanting & 1,500 & 02.00 \\
\hline Fertilizer input & 21,000 & 38.00 \\
\hline Labor input & 7,000 & 13.00 \\
\hline Pesticides & 3,000 & 05.00 \\
\hline Harvesting & 4,000 & 07.00 \\
\hline Total Variable Cost & 38,500 & 69.00 \\
\hline \multicolumn{3}{|l|}{ (b) Fixed Cost } \\
\hline Depreciation of farm assets & 4,000 & 07.00 \\
\hline Costs incurred on land & 5,000 & 09.00 \\
\hline \multicolumn{3}{|l|}{ Expenses Spent on } \\
\hline Administrative procedures & 4,500 & 08.00 \\
\hline Taxes & 2,000 & 04.00 \\
\hline Interest & 1,700 & 03.00 \\
\hline Total Fixed Cost & 17,200 & 31.00 \\
\hline Total Cost of Production & 55,700 & 100.00 \\
\hline Total Returns & 800,000 & \\
\hline Gross Margin & 761,500 & \\
\hline Net Farm Income & 744,300 & \\
\hline Operating Ratio & 0.051 & \\
\hline Gross Margin Ratio & 0.951 & \\
\hline Rate of Return on Investment & 13.36 & \\
\hline
\end{tabular}

Source: field survey, 2019. Computed using STATA Version 14.

\section{Factors influencing rice farmers' decision to obtain an agricultural loan}

In the first stage of the Heckman two-stage model, factors influencing the choice of rice farmers to obtain an agricultural loan are presented in Table 3. The statistical and significant exogenous variables included in the model consisted of age $(P<0.01)$, marital status $(P<0.05)$, household size $(P<0.10)$, educational level $(P<0.05)$, farm size $(P<0.05)$, farm and non-farm income $(P<0.10)$, farm experience $(P<0.05)$, collateral property $(P<0.05)$, extension services $(P<0.10)$, and awareness of loan or credit facilities $(P<0.05)$. The results concerning marginal probabilities were also presented in Table 3. Education and literacy increase the likelihood of rice farmers deciding or choosing to obtain an agricultural loan by 0.1400 . The ability to read facilitates undertaking the rigorous administrative procedures involved in getting an agricultural loan. Furthermore, acquiring more collateral property increases the likelihood of rice farmers obtaining an agricultural loan from financial institutions by 0.1702 . Collateral properties are required before financial institutions can extend agricultural loans to farmers (Alabi, Lawal, and Chiogor, 2016).

The log-likelihood ratio and the Wald chi-square were -117.788 and 88.91 ; they were significant at the $1 \%$ probability level. The pseudo- $\mathrm{R}^{2}$ means that the exogenous variables included in the model explained $81.21 \%$ of variations in the decision to obtain an agricultural loan from financial institutions by rice farmers. This result is in line with findings of Saqib et al. (2018), Ettah and Ebu (2018), Otunaiya et al. (2014), Olagunju and Adeyemo (2007), Isibor and Nkamigbo (2019), Nimoh et al. (2013), and Fikadu (2016), who reported in their findings that socio-economic factors influence the decision of farmers to obtain an agricultural loan.

\section{Socio-economic factors influencing the amount of agricultural loan obtained} In the second stage of the Heckman two-stage model, the socio-economic factors of interest influencing the amount of loan obtained from financial institutions were presented in Table 3. The statistical and significant predictor variables influencing the amount of loan obtained from financial institutions included age $(P<0.05)$, sex $(P<0.01)$, household size $(P<0.05)$, educational level $(P<0.01)$, and farm size $(P<0.05)$. Farm size has a positive coefficient. An increase in the size of rice farms by one hectare increases the likelihood of rice farmers obtaining an agricultural loan. Educational level has a positive coefficient, which implies that rice farmers' education and literacy increase the likelihood, propensity, or probability of obtaining a larger loan from financial institutions, so the farmer would be able to utilize or make use of the loan obtained judiciously. The $\mathrm{R}^{2}$-value was 0.8611 , suggesting that the exogenous variables included in the model explained $86.11 \%$ of variations in the dependent variable, which is the agricultural loan amount granted to the rice farmers. The F-value of 351.02 was significant at the $1 \%$ probability 
Alabi, O. O., Oladele, A. O., Usman, M. B. (2021). Determinants of agricultural loan decision making process for rice (Oryza sativa) farmers in Abuja, Nigeria. Applications of Heckman two-stage model and factor analysis. J. Agribus. Rural Dev., 1(59), $29-38$. http://dx.doi.org/10.17306/J.JARD.2021.01381

Table 3. Parameter estimates of the Heckman two-stage model

\begin{tabular}{lcccc}
\hline \multirow{2}{*}{ Variables } & \multicolumn{2}{c}{ Probit access model } & \multicolumn{2}{c}{ OLS amount model } \\
\cline { 2 - 5 } & coefficient & marginal effects & coefficients & t-value \\
\hline Age $\left(X_{1}\right)$ & $0.032^{* * *}$ & 0.2134 & $0.3101^{* *}$ & 2.51 \\
Sex $\left(X_{2}\right)$ & - & - & $0.0451^{* * *}$ & 3.54 \\
Marital status $\left(X_{3}\right)$ & $0.0014^{* *}$ & 0.1401 & 0.0163 & 1.01 \\
Household size $\left(X_{4}\right)$ & $0.1786^{*}$ & 0.1109 & $0.1921^{* *}$ & 2.51 \\
Educational level $\left(X_{5}\right)$ & $0.1278^{* *}$ & 0.1400 & $0.2106^{* * *}$ & 3.72 \\
Farm size $\left(X_{6}\right)$ & $0.0981^{* *}$ & 0.1703 & $0.4105^{* *}$ & 2.62 \\
Farm and non-farm income $\left(X_{7}\right)$ & $0.2398^{*}$ & 0.1901 & - & - \\
Farm experience $\left(X_{8}\right)$ & $0.4891^{* *}$ & 0.3103 & $0.3214^{* * *}$ & 3.87 \\
Collateral property $\left(X_{9}\right)$ & $0.2281^{* *}$ & 0.1702 & $0.1725^{* *}$ & 2.87 \\
Extension services $\left(X_{10}\right)$ & $0.1238^{*}$ & 0.1908 & $0.1540^{* *}$ & 2.61 \\
Awareness of loan/credit $\left(X_{11}\right)$ & $0.3319^{* *}$ & 0.2210 & $0.2503^{* * *}$ & 3.81 \\
Inverse Mill ratio $\left(X_{12}\right)$ & - & - & $0.6102^{* *}$ & 2.58 \\
Number of observations & 100 & - & - & - \\
Wald chi-square & $88.91^{* * *}$ & - & - & - \\
Log-likelihood & -117.788 & - & 0.8684 & 0.8611 \\
Pseudo $R^{2}$ & 0.8121 & - & $351.02^{* * *}$ & \\
$R^{2}$-value & - & - & & \\
Adjusted $R^{2}$ & - & & - & \\
$F$-value & & & & \\
\hline & & - & & \\
\hline
\end{tabular}

Source: field survey, 2019. Computed using STATA Version 14.

*** Significant at $P<0.01, * *$ significant at $P<0.05$, * significant at $P<0.10$.

level. It justifies that all exogenous variables included in the models were jointly responsible for influencing the amount of agricultural loan obtained by rice farmers. This result is in line with findings of Saqib et al. (2018), Ettah and Ebu (2018), Otunaiya et al. (2014), Olagunju and Adeyemo (2007), Isibor and Nkamigbo (2019), Alabi et al. (2016), Nimoh et al. (2013), and Fikadu (2016).

\section{Constraints or problems facing rice farmer}

The constraints faced by rice farmers in obtaining agricultural loans and production activities were examined using principal component analysis. Principal component analysis transformed many variables that were interrelated with smaller variables that were not interrelated. Lack of collateral property and complicated and costly administrative procedures constituted significant constraints facing rice farmers in obtaining agricultural loans; they were ranked 1st and 6th with eigenvalues of 2.1302 and 1.5055 , respectively. Lack of fertilizers, inadequate road infrastructures, lack of credit facilities, and labor inputs constituted major constraints facing rice farmers in production activities; they were ranked $2 \mathrm{nd}, 3 \mathrm{rd}$, 4 th, and 5th with eigenvalues of 2.0091, 2.0002, 1.9301, and 1.6701, respectively. This result is similar to previous studies by Alabi et al. (2020) that used principal component analysis to examine rural rice farmers' constraints. All constraints facing rice farmers in obtaining agricultural loans and production activities explained $93.85 \%$ of all the model variables. The Kaiser-Meyer-Olkin (KMO) measure of sampling adequacy was applied and estimated at 0.821 . The Bartlett test of sphericity gave a value of 3002.109 and was significant at $P<0.01$. 
Alabi, O. O., Oladele, A. O., Usman, M. B. (2021). Determinants of agricultural loan decision making process for rice (Oryza sativa) farmers in Abuja, Nigeria. Applications of Heckman two-stage model and factor analysis. J. Agribus. Rural Dev., 1(59), $29-38$. http://dx.doi.org/10.17306/J.JARD.2021.01381

Table 4. Results of the principal component analysis of constraints or problems facing rice farmers

\begin{tabular}{lcccc}
\hline \multicolumn{1}{c}{ Constraints } & Eigenvalue & Difference & Proportion & Cumulative \\
\hline Lack of collateral property & 2.1302 & 0.1321 & 0.1670 & 0.1670 \\
Lack of fertilizer inputs & 2.0091 & 0.3210 & 0.2216 & 0.3886 \\
Poor-quality feeder roads & 2.0002 & 0.2291 & 0.1650 & 0.5536 \\
Lack of credit facilities & 1.9301 & 0.2167 & 0.1219 & 0.6755 \\
Inadequate labor inputs & 1.6701 & 0.1430 & 0.1619 & 0.8379 \\
Complicated and costly admin- & 1.5055 & 0.1218 & 0.1011 & 0.9385 \\
istrative procedures & & & & \\
\hline
\end{tabular}

Bartlett test of sphericity

KMO 0.821

Chi-Square 3002.109***

Rho 1.00000

Source: field survey, 2019. Computed using STATA Version 14.

\section{CONCLUSIONS}

The rice production activities were rigorous and laborious and carried out by young, energetic, and resourceful farmers. The mean age of rice farmers was 46.90 years. The rice farmers were literate and had formal education. The average experience in rice farming activities was 8 years. The household sizes were large, with an average of 6 persons per household. On average, about 71,550 nairas were obtained from financial institutions as a loan by rice farmers. The average farm size was 1.49 hectares. Rice production was profitable with a net farm income of 744,300 nairas. The gross margin ratio of 0.95 shows that 95 kobos covered profits, taxes, interest, expenses, and depreciation for every naira invested in rice production activities. Factors statistically and significantly influencing the decisionmaking process in obtaining an agricultural loan by rice farmers were age, marital status, household size, educational level, farm sizes, farm and non-farm income, farm experiences, collateral property, extension services, and access loan or credit facilities. The socio-economic factors statistically and significantly influencing the amount of loan obtained by rice farmers were age, sex, household size, and educational level. Constraints facing rice farmers in production activities and obtaining agricultural loans included lack of collateral property, lack of fertilizer input, poor-quality feeder roads, lack of credit facilities, inadequate labor inputs, and complicated and costly administrative procedures. These constraints explained $93.85 \%$ of all variables included in the model.

\section{RECOMMENDATIONS}

The following policy recommendations were developed based on the findings of this study:

(i) The average amount of loan obtained by rice farmers was 71,550 nairas. This amount is likely to be inadequate considering the capital involved in rice farming activities. Therefore, agricultural loans should be made available to rice farmers in sufficient amounts at low-interest rates and devoid of cumbersome and costly administrative procedures.

(ii) The government should construct feeder roads infrastructures for easy movement of rice produce from farm gate to market centers.

(iii) Farm inputs, including chemicals, fertilizers, improved seeds, irrigation facilities, should be provided to rice farmers at the appropriate time.

(iv) Extension officers should be employed to assist in disseminating research findings from institutions to farmers.

(v) Collateral security required by financial institutions before extending agricultural loans to rice farmers should be abolished. Rice farmers are small-scale peasants and poor and so do not have any collateral property. 


\section{REFERENCES}

Agbogo, E.A., Uduoso, A.B., Tiku, E.N. (2013). Analysis of Factors Affecting Rice Consumption in Cross River State, Nigeria. J. Agric. Vet. Sci., 4(2), 34-40.

Alabi, O.O., Lawal, A.F., Chiogor, H.O. (2016). Access to Formal Credit Facilities among Smallscale Crop Farmers in Gwagwalada Area Council, Abuja, Nigeria. Russ. J. Agric. Soc.-Econ. Sci., 1(49), 57-66.

Alabi, O.O., Oladele, A.O., Oladele, N.O. (2020). Socio-Economic Factors Influencing Perceptions and Adaptability of Rural Rice Farmers to Climate Change, Abuja, Nigeria: Applications of Heckman Two - Stage Model. Russ. J. Agric. Soc.-Econ. Sci., 8(104), 45-56.

Alabi, O.O., Adebayo, O., Akinyemi, A., Apene, E. (2004). Sources and Accessibility of Credit to Rural Women in Chikun Local Government Area of Kaduna State. Int. J. Econ. Dev. Iss. 4(1 \& 2), 106-113.

Alabi, O.O. (2008). Impact of Microcredit Scheme of Nigerian Agricultural Cooperative and Rural Development Bank on Annual Crop Farmers in Bakori Local Government Area of Katsina State. Int. J. Sust. Tropic. Agric. Res., 28, 22-26.

Bamiro, O.M., Otunaiya, A.O., Idowu, A.O. (2012). Economics of Horizontal Integration in Poultry Industry in South West Nigeria. Int. J. Poul. Sci., 11, 39-46.

Bashir, M.K., Mehmood, Y., Hassan, S. (2010). Impact of Agricultural Credit on Productivity of Wheat Crop: Evidence from Lahore, Punjab, Pakistan. Pak. J. Agric. Sci., 47(4), 405-409.

Ben-Chendo, G.N., Lawal, N., Osuji, M.N., Osugiri, I.I., Ibeagwa, B.O. (2015). Cost and Returns of Paddy Rice Production in Kaduna State of Nigeria. Int. J. Agric. Market., 2(5), 084-089.

Eboh, E.C., Nwafor, M., Chukwu, J.O., Amuka, J.I. (2011). Cost-Effective Agriculture Growth Options for Poverty Reduction in Nigeria: Evidence and Policy Implications. African Institute for Applied Economics, Research Paper 6.

Essien, U.A., Arene, C.J., Nweje, N.J. (2013). What Determine the Frequency of Loan Demand in Credit Markets among Agro Based Enterprises in the Niger Delta Region of Nigeria? An Empirical Analysis.

Ettah, O.I., Ebu, B.O. (2018). Determinants of Agricultural Loan Access from Formal Sources in Cross River State Central Agricultural Zone, Nigeria. Int. J. ResearchGRANTH., 6(5), 1-8.

FAOSTAT (2005). Food and Agricultural Organization. Statistical Data Base. Rome: FAO.

FMARD (Federal Ministry of Agriculture and Rural Development). (2014). Report of the 2013 Wet Season Farm Output/Agricultural Production Survey (APS).
Fikadu, G.F. (2016). Determinants of Access to Credit and Credit Sources Choice by Micro, Small and Medium Enterprises in Nekemte, Ethiopia. Int. J. Afr. Asian Stud., 28, $11-27$.

IRRI (International Rice Research Institute). (2001). Report 2001.

Isibor, A.C., Nkamigbo, D.C. (2019). Economic Determinants of Loan Repayment to Large and Smallscale Farmers Beneficiaries of Bank of Agriculture Loans from 2010-2016 in Anambra State, Nigeria. Int. J. Agric. Pol. Res., 7(4), 91-99.

Lawal, A.F., Alabi, O.O. (2011). Factors Affecting Adoption of New Rice For Africa (NERICA) and Complimentary Technology in Southern Guinea Savannah, Niger State, Nigeria. Int. J. Agric. Dev. Econ. (IJADE), 1(2), 121-128.

Nimoh, F., Tham-Agyekum, E.K., Awuku, M.S. (2013). Factors Influencing Access of Poultry Farmers to Credit: The Case of the Agricultural Development Bank (ADB) in Ga East Municipal, Ghana. Management, 3(1), 54-58

Nkamigbo, D.C., Ugwumba, C.O.A., Okeke, U. (2009). Market Structure, Conduct, and Volume of Trade among Channels of Watermelon Marketing in Anambra State, Nigeria. Int. J. Agric. Biosci., 8(2), 112-116.

NPC (2006). National Population Commission of Nigeria, Population Census 2006.

Nwaru, J.C. (2011). Determinants of Informal Credit Demand and Supply among Food Crops. Farmers in Akwa Ibom State, Nigeria. J. Rural Comm. Dev., 13(1), 200-211.

Olagunju, F.I., Adeyemo, R. (2007). Determinants of Repayment Decision among Smallholder Farmers in Southwest Nigeria. Pak. J. Soc. Sci., 4(5), 677-686.

Olukosi, J.O., Erhabor, P.O. (2005). Introduction to Farm Management Economics: Principles and Applications (pp. 77-83). Zaria, Kaduna, Nigeria: Agitab Publishers Limited.

Otunaiya, A.O., Ologbon, O.A.C., Akerele, E.O. (2014). Analysis of Agricultural Loan Use Decision among Poultry Farmers in Oyo State, Nigeria. Inte. J. Poul. Sci., 13(2), 108-113.

Saboor, A., Hussaini, A., Taqi, M. (2014). Impact of Agricultural Credit on Agricultural Productivity in Pakistan: An Empirical Analysis. Int. J. Adv. Res. Manag. Soc. Sci., 3(4), 125-139.

Saqib, S.E., Kuwornu, J.K.M., Panezia, S., Ali, U. (2018). Factors Determining Subsistence Farmers' Access to Agricultural Credit in Flood-Prone Areas of Pakistan. Kaset. J. Soc. Sci., 39, 262-268. 